\title{
Evaluating Starter N Application to Soybean With CROPGRO-Soybean Model in the Southern Guinea Savanna Agro-Ecology of Nigeria
}

\author{
Olukayode Stephen Oyatokun $^{1} \&$ Kolapo Olatunji Oluwasemire ${ }^{1}$ \\ ${ }^{1}$ Department of Agronomy, University of Ibadan, Ibadan, Nigeria \\ Correspondence: Olukayode Stephen Oyatokun, Department of Agronomy, University of Ibadan, Ibadan, Nigeria. \\ E-mail: steveoyatokun@yahoo.com
}

Received: April 18, 2014 Accepted: June 2, 2014 Online Published: July 15, 2014

doi:10.5539/jas.v6n8p83 URL: http://dx.doi.org/10.5539/jas.v6n8p83

\begin{abstract}
Nitrogen $(\mathrm{N})$ is essential for the growth and development of crops. It is a major soil nutrient for soybean. Deficiency of nitrogen in soil before soybean root nodule formation constitutes the most limiting factor after soil moisture for its production. This study was undertaken to determine starter $\mathrm{N}$ application rate for optimum soybean yield for two soybean varieties; assess Cropgro-soybean model and project soybean yield under different $\mathrm{N}$ use.

Two field experiments were set up in a $5 \times 2$ split-plot arrangement in a randomized complete block design in 2009 and 2010. The $\mathrm{N}$ doses of 0 (control), 5, 15, 25 and $35 \mathrm{~kg} \mathrm{~N} /$ ha were applied one week after planting using urea to form the main plot and soybean varieties (TGx1485-1D and TGx1448-2E) constituted the sub-plot with three replications. Designated samples were used to evaluate 100 seed weight, plant dry biomass and harvest index. Data obtained were subjected to analysis of variance and means separated with least significant difference at $\mathrm{p} \leq 0.05$. Crop phenological data and yield at harvest were used for Decision Support System for Agrotechnology Transfer (DSSAT) Cropgro-Soybean model calibration and yield projection under different $\mathrm{N}$ use. Root mean square error (RMSE) and percentage error (PE) were used to analyze model outputs. The soil water balance output of the model was reviewed for explaining the components of water output in the environment.
\end{abstract}

Field studies showed significant differences $(p \leq 0.05)$ in varietal response to seed weight and biomass production where variety TGx1448-2E produced a significantly higher 100 seed weight and higher plant dry biomass. Genotypic superiority of TGx1448-2E over TGx1485-1D is suggested. There was high accuracy in prediction of soybean phenology (i.e. PE $<10 \%$ ) for both varieties, although high PE $(>15 \%)$ were obtained for yields of TGx1448-2E. The model accurately predicted soybean phenology to within $0-1$ day of the field observed values. The soil water balance indicated 39-45 \% loss of the total seasonal rainfall to runoff and 3-11 \% through deep drainage.

The application of $\mathrm{N}$ starter-dose was not effective in enhancing yield of soybean in the study-sites owing to the occurrences of intensive rainfall events that led to runoff and the loss of applied $\mathrm{N}$ during the cropping season.

Keywords: N starter-dose, soybeans, soil water balance, phenology, root mean square error, model

\section{Introduction}

Worldwide interest and attention in soybean is mainly due to its high nutritional value and seed protein content (Tiamigu \& Idowu, 2001). Soybean is widely cultivated in most parts of the world and also reputed to have a lot of potential in Africa (Adamu \& Amatobi, 2001; Steve \& Jonathan, 2001). The oil produced from soybean is highly digestible and contains no cholesterol. A by-product from the oil production (soybean cake) is used as a high-protein animal feed in many countries. Soybean also improves soil fertility by adding nitrogen from the atmosphere. This is a major benefit in African farming systems, where soils have become exhausted by the need to produce more food for increasing populations, and where fertilizers are hardly available and are expensive for farmers. The total land area under soybean in the world was 95.2 million ha and total production was 212.6 million tons (FAOSTAT, 2005). The three major soybean - producing countries were USA (29 million ha), Brazil (23 million ha), and Argentina (14 million ha). In terms of total production, USA produced 83 million 
tons, followed by Brazil (51 million tons) and Argentina (38 million tons). In Africa, soybean was grown on an average of 1.16 million hectares with an average production of 1.26 million tons (FAOSTAT, 2005). African countries with the largest area of production were Nigeria (601 000 ha), South Africa (150 000 ha), Uganda (144 $000 \mathrm{ha}$ ), Malawi (68 $000 \mathrm{ha}$ ), and Zimbabwe (61 $000 \mathrm{ha)}$ ). Other countries with sizeable areas are Rwanda (42 $160 \mathrm{ha}$ ), DRC (30 $000 \mathrm{ha})$, and Zambia (15 $000 \mathrm{ha})$. Grain yields of soybean cultivars are generally low in Nigeria compared to other places in the world. There is therefore a wide gap between what is currently being produced and what is needed. Increasing soybean production to meet the required quantities can best be achieved through an increase in yield per unit area, which can partly be achieved by the cultivation of high-yielding improved varieties and improved agronomic practices. In spite of its great potential, soybean production is still on a small scale in Nigeria owing to various limitations which result in low yield per unit area. There is need to improve soybean production in order to bridge gap between production and domestic/industrial demands. Due to variability in rainfall pattern especially rainfall distribution/amount and in order to further understand the underlying factors that could be responsible for the performance of soybean in the study region, Decision Support System for Agrotechnology Transfer (DSSAT) model application was used to test the reliability of data measured and to unravel the dynamics of activities that occurred within the soil system as a result of $\mathrm{N}$ fertilizer application in the face of the prevailing weather conditions. Crop models are available for almost all economically important crops and have the ability to predict yield and evaluate different options to maximize profit and/or minimize losses of nutrients or chemicals by integrating the effects of daily weather data with soil characteristics and management practices (Boote et al., 1998). The CROPGRO - Soyabean is one of the crop simulation models that is included in the DSSAT (Tsuji et al., 1994; Hoogenboom et al., 1999; Jones et al., 2001) and has been used in many applications around the world (Boote et al., 1998; Tsuji et al., 1994). The model is physiologically based and simulates the productivity of soybean cultivars under various management and environmental conditions (Singh et al., 1994, Boote et al., 1998). CROPGRO-Soyabean model is a process-oriented model that can be used to study soyabean response to management (Egli \& Bruening, 1992), environmental conditions (Curry et al., 1995) and genetic yield potential (Boote \& Tollenaar, 1994). It has also been used to study causes of spatial yield variability (Allen et al., 1996; Paz et al., 1998). The model requires inputs of management practices and environmental conditions, and incorporates knowledge of cultivar specific traits (genetic coefficients) to predict daily growth and development as the plant responds to weather, soil characteristics and management practices (Boote et al., 1998; Paz et al., 1998).

There have also been inconsistencies in the recommendations on the requirement for $\mathrm{N}$ at the early growth stage of grain legumes. For instance, $20 \mathrm{~kg} \mathrm{~N} \mathrm{ha}^{-1}$ was recommended for Bambara nut on an alfisol in Zaria in the Northern Guinea Savanna of Nigeria (Tanimu \& Yayock, 1990). The ever increasing population growth in the sub-Saharan Africa puts much pressure on available land for crop production. There is also high intensity or continuous use of land resulting in annual yield decline. Sustenance of land productivity requires the availability of plant nutrients, principal among which is nitrogen. Soybean, like other legumes, can fix atmospheric $\mathrm{N}_{2}$ for its use. However, this ability could be disturbed if nitrogen is deficient in soil. The soils of the Oyo north area of south west Nigeria, which falls in the southern guinea savanna agro-ecology zone of Nigeria is derived from the basement complex which is at an advanced weathering form and characterized by low cation exchange capacity to supply and/or retain plant nutrients. This low capacity has marked consequences for fertilizer application and soil fertility management. The application of soil nutrients, especially $\mathrm{N}$, is required to ameliorate leaching and runoff losses because of the high intensity of rainfall events in this area. In an attempt to exploit the interplay between rainfall and soil moisture; rainfall seasonality, crop water consumption, rainfall intensity and flooding are expected to give an insight into the fate of applied nutrients to soils. To understand the underlying factors responsible for soybean performance in the study-area, DSSAT model application was used to test the reliability of soybean crop phenology and to unravel the dynamics of activities that occurred within the soil system as a result of $\mathrm{N}$ fertilizer application in the face of the prevailing weather conditions. This study thus sought to evaluate the influence of starter-dose of nitrogen on the performance of two soybean varieties on ferric luvisols in the Southern Guinea Savanna of Nigeria with the objectives of determining starter N application rate for optimum soybean yield for two soybean varieties; validating the reliability of data measured as well as project soybean yield under different $\mathrm{N}$ use in the moist/humid agroecological zone of Nigeria.

\section{Materials and Methods}

\subsection{Study Location}

Field trials were carried out in two locations namely: Ipapo (Latitude $8^{\circ} 08^{\prime} \mathrm{N}$; Longitude $03^{\circ} 30^{\prime} \mathrm{E}$; $353 \mathrm{~m}$ asl) and Gbonran (Latitude $8^{\circ} 06^{\prime} \mathrm{N}$; Longitude $03^{\circ} 30^{\prime} \mathrm{E}$; $379 \mathrm{~m}$ asl) both situated in Itesiwaju Local Government Area of Oyo State lying within the Southern Guinea Savanna agro-ecology of Nigeria. The mean annual rainfall of the 
area varies from $1000 \mathrm{~mm}$ - $1400 \mathrm{~mm}$ with most of the rainfall concentrated between April and October and well-marked wet and dry seasons. In August, there is usually a short dry spell in between the rainy months. Temperatures are usually high throughout the year with an annual mean of $27^{\circ} \mathrm{C}$. Relative humidity is high and varies from $60-80 \%$.

According to FAO-UNESCO World soil map, luvisols are the most prevalent (about 70\%) in the area. Arenosols, fluvisols, lithosols and nitosols are also found. Most of the soils vary in texture with depth, and have sandy topsoil over more clayey subsoil (FAO, 1988).

\subsection{Meteorological Data}

Daily data for precipitation, evapo-transpiration, minimum and maximum temperatures for a period of thirty (30) years were obtained from the observation station of the Nigerian Meteorological Agency (NIMET), Iseyin Zonal Office which is at a distance of about $10 \mathrm{~km}$ to the two fields. Monthly and annual totals were computed for precipitation and evapo-transpiration while the mean monthly temperature values were computed as:

$$
\left[\sum(\mathrm{Dmax}+\mathrm{Dmin} / 2)\right] / \mathrm{Ndays}
$$

Where,

Dmax $=$ Daily maximum temperature;

Dmin $=$ Daily minimum temperature;

Ndays $=$ Number of days in the specific month.

\subsection{Experimental Procedures and Design}

Surface soil samples $(0-15 \mathrm{~cm})$ were collected from 15 spots on each selected field with a shovel and bulked (mix thoroughly) to form a composite. The samples from the two locations were collected separately, air dried and passed through 2mm-sieve. A sub-sample of each composite was taken for pre-planting analysis.

Two promiscuous soybean varieties, TGx1448-2E and TGx1485-1D obtained from the International Institute of Tropical Agriculture (IITA), Ibadan were used for this study.

A total land area of $665 \mathrm{~m}^{2}$ was allocated for the field trial in each of the experimental location. The land was cleared, marked and pegged into $5 \mathrm{~m} \times 4.5 \mathrm{~m}\left(22.5 \mathrm{~m}^{2}\right)$ plots. There were five (5) sub-plots. Oba $98 \mathrm{maize}$ hybrid (quality protein maize with high nitrogen requirements) was used to mop up the native nitrogen and was uprooted when signs of $\mathrm{N}$ deficiency were noticed. The experiment was laid out as a $5 \times 2$ split-plot arrangement with treatments replicated three times in a randomized complete block design. Nitrogen application doses of 0 (control), 5, 15, 25 and $35 \mathrm{~kg} \mathrm{~N} /$ ha were at the main plot while soybean varieties TGx148-1D and TGx1448-2E were at the sub-plot. Planting was done at the two experimental locations by $28^{\text {th }}$ June 2009 for the first year planting season and on the $11^{\text {th }}$ June 2010 for the second year season at a planting distance of $75 \mathrm{~cm} \times 5 \mathrm{~cm}, 1$ soybean seed/hole and 3-4 cm planting depth to give a total plant population of 266,667 plants per hectare. Starter $\mathrm{N}$ was applied in the form of urea $(46 \% \mathrm{~N})$ by banding at 1week after planting (WAP) while weeding was done by hoeing once before canopy establishment. Parameters measured are soybean phenological data (i.e. days to emergence, anthesis, first pod, first seed, physiological maturity), weight of 100 seeds, dry shoot weight, harvest index, shoot $\mathrm{N}$ content and dry seed weight. Data obtained were subjected to analysis of variance procedures using GENSTAT Discovery Edition 3 (Genstat, 1995). Means were also separated with least significant difference (LSD) at 5\% probability level (Steel \& Torrie, 1987).

\subsection{Model Calibration}

The crop simulation model, CROPGRO-Soybean model, uses 15 genetic coefficients to define development and growth characteristics of a soybean cultivar. The calibration process is a systematic search of possible values that the model will use to predict accurately the observed parameters. Phenological data on emergence, anthesis and physiological maturity were collected. Dates were noted when $50 \%$ of plant population attained a particular stage. Genetic coefficient for this study was obtained following the procedures described by Mavromatis et al. (2001).

\subsection{Model Validation}

Crop growth and development data were inputted and run with DSSAT cropping system model software (Version 4.2). Experimental outputs were analyzed for measured and simulated output to test reliability of measured results. The set of data required to run the crop model and validate outputs is referred as a minimum data set (MDS) include: daily weather data for the duration of the growing season, site soil data and management and experimental data for the trials. 
The minimum data set for weather data are the latitude and longitude of the weather station, daily records of incoming solar radiation $\left(\mathrm{MJ} / \mathrm{m}^{2}\right.$ day), maximum and minimum air temperature $\left({ }^{\circ} \mathrm{C}\right)$ and daily record of rainfall $(\mathrm{mm})$.

\subsection{Soil Description for Model Work}

Profile pits of $1 \mathrm{~m} \times 1 \mathrm{~m} \times 2 \mathrm{~m}$ depth were dug and soil sampled according to the genetic horizons interval for the two locations (Ipapo and Gbonran), described according to FAO guideline (2006) and classified. The soil characteristics and morphological properties were described for each of the identified horizons in the profiles.

After the description of the site and soil profiles, samples were taken from each of the soil profiles, bagged and appropriately labeled for laboratory analysis. Soil were subsequently classified at series level according to Murdoch et al. (1976) while higher level of soil classification was based on USDA soil taxonomy (2010). A soil file compatible with the DSSAT input requirement was prepared using SBuild program that estimates Drained Upper Limit (DUL), Lower Limit of plant extractable soil water (SLLL), soil hydraulic conductivity (SSKS) and saturated moisture content (SSAT) of different layers of the soil (IBSNAT, 1998).

\subsection{Statistical Analysis of Model Data}

The predicted and observed values of soybean phenological characteristics such as number of days to anthesis, first pod, first seed and physiological maturity were analyzed to test the reliability of data. A simple way of expressing error is to express root mean square error as percentage of means of observation i.e. Percentage error (PE). If $\mathrm{PE}$ is less than ten percent, the prediction is acceptable.

The equations are as written below:

$$
\begin{gathered}
\mathrm{RMSE}=\sqrt{ }\left[\sum(\mathrm{Pi}-\mathrm{Oi})^{2} / \mathrm{n}\right] \\
\mathrm{PE}=\mathrm{RMSE} / \overline{\mathrm{O}} \times 100
\end{gathered}
$$

Where,

RMSE $=$ Root mean square error;

$\mathrm{Pi}=$ predicted value;

$\mathrm{Oi}=$ observed value;

$\overline{\mathrm{O}}=$ mean of observed value;

$\mathrm{n}=$ number of replicates/locations;

$\Sigma=$ Summation sign;

$\sqrt{ }=$ Square root.

\subsection{Soil Water Balance}

Soil water infiltration during a day was computed by subtracting surface runoff from rainfall that occurs on that day. The SCS method (Soil Conservations Service, 1972) was used to partition rainfall into runoff and infiltration, based on a 'curve number' that attempts to account for texture, slope, and tillage. The modification to this method developed by Williams et al. (1984) was used in the model and it accounts for layered soils and soil water content at the time when rainfall occurs.

\section{Results}

\subsection{Soil Properties}

Some of the physico-chemical properties of the soils in both fields are $\mathrm{pH} 6.4$ showing that the soils are slightly acidic, which is within the optimum range of 5.8 to 7.0 recommended for soybean (PCARRD/USDA, 1986). Total $\mathrm{N}(\mathrm{g} / \mathrm{kg}) 0.7$ and 1.0; organic $\mathrm{C}(\mathrm{g} / \mathrm{kg}) 8.6$ and 12.1; available $\mathrm{P}(\mathrm{mg} / \mathrm{kg}) 6.3$ and 7.3 , and $\mathrm{K}(\mathrm{cmol} / \mathrm{kg}) 0.2$ apiece for Ipapo and Gbonran respectively (Table 1). These shows that the soils in both locations are inherently low in fertility. The total $\mathrm{N}$, available $\mathrm{P}$ and exchangeable $\mathrm{K}$ were very low and the organic matter content was also low. The soils textural class is loamy sand.

\subsection{Meteorological Data}

The annual rainfall values were $935.5 \mathrm{~mm}$ and $1475.8 \mathrm{~mm}$ in 2009 and 2010 respectively. Potential evapotranspiration (PET) values were $1676.5 \mathrm{~mm}$ and $1676.8 \mathrm{~mm}$ in 2009 and 2010 respectively (Table 2). This implies that an annual moisture deficit of $741 \mathrm{~mm}$ in 2009 and $219 \mathrm{~mm}$ in the 2010 were recorded. These deficits were however encountered for five months (November, December, January, February and March) which are regarded as the dry season in the region. Temperature values range from $24{ }^{\circ} \mathrm{C}$ to $29.8^{\circ} \mathrm{C}$ in both years and the 
mean monthly temperature for 2009 was $26.5^{\circ} \mathrm{C}$ and $27.1{ }^{\circ} \mathrm{C}$ for 2010 . The mean monthly temperatures in the study period were all within the $20-30{ }^{\circ} \mathrm{C}$ which is the recommended optimum temperature range for soybean production.

Table 1. Physical and chemical properties ipapo and gbonran soils used

\begin{tabular}{llll}
\hline Parameters & Units & Ipapo & Gbonran \\
\hline $\mathrm{pH}\left(\mathrm{H}_{2} \mathrm{O}\right)$ & $\mathrm{g} / \mathrm{kg}$ & 6.4 & 6.4 \\
Total Nitrogen & $\mathrm{g} / \mathrm{kg}$ & 8.7 & 1.0 \\
Organic Carbon & $\mathrm{mg} / \mathrm{kg}$ & 6.3 & 12.1 \\
$\mathrm{Avail} . \mathrm{P}$ & $\mathrm{c} \mathrm{mol} / \mathrm{kg}$ & 1.3 & 7.3 \\
$\mathrm{Ca}$ & $"$ & 1.1 & 1.9 \\
$\mathrm{Mg}$ & $"$ & 0.2 & 1.2 \\
$\mathrm{~K}$ & $"$ & 0.3 & 0.2 \\
$\mathrm{Na}$ & & 0.2 & 0.3 \\
$\mathrm{Exch}$. Acidity & $\mathrm{mg} / \mathrm{kg}$ & 27.0 & 0.3 \\
$\mathrm{Fe}$ & $"$ & 98.2 & 29.8 \\
$\mathrm{Mn}$ & $"$ & 2.1 & 130.3 \\
$\mathrm{Cu}$ & $"$ & 1.3 & 2.6 \\
$\mathrm{Zn}$ & & & 1.5 \\
Particle size analysis $(\mathrm{g} / \mathrm{kg})$ & & 48 & \\
Clay & & 80 & 68 \\
Silt & & 872 & 120 \\
Sand & & Loamy Sand & \\
Textural Class & & &
\end{tabular}

Table 2. Total monthly rainfall, potential evapotranspiration and mean monthly temperature for Iseyin, Oyo State, Nigeria (2009-2010)

\begin{tabular}{ccccccc}
\hline Month & \multicolumn{2}{c}{ Rainfall $(\mathrm{mm})$} & $\begin{array}{r}\text { Potential Evapotranspiration } \\
(\mathrm{mm})\end{array}$ & $\begin{array}{c}\text { Mean Monthly } \\
\text { Temperature }\left({ }^{\circ} \mathrm{C}\right)\end{array}$ \\
\hline Jan & 2009 & 2010 & 2009 & 2010 & 2009 & 2010 \\
Feb & 2.1 & 0.0 & 170.2 & 170.2 & 27.8 & 28.7 \\
Mar & 10.6 & 19.5 & 174.0 & 168.2 & 28.1 & 29.8 \\
Apr & 29.0 & 131.6 & 169.4 & 169.9 & 29.5 & 29.1 \\
May & 102.4 & 43.5 & 149.0 & 149.8 & 27.0 & 28.9 \\
Jun & 130.7 & 204.4 & 127.4 & 128.2 & 26.9 & 27.1 \\
Jul & 217.9 & 167.5 & 115.1 & 115.3 & 25.7 & 26.7 \\
Aug & 74.5 & 205.7 & 111.5 & 110.9 & 24.0 & 24.9 \\
Sep & 108.9 & 256.5 & 121.5 & 120.8 & 24.5 & 25.8 \\
Oct & 117.8 & 240.5 & 136.2 & 136.5 & 25.8 & 25.9 \\
Nov & 2.1 & 101.4 & 138.5 & 138.5 & 26.1 & 26.8 \\
Dec & 0.0 & 0.0 & 155.2 & 160.0 & 27.3 & 27.1 \\
Total/Mean & 935.5 & 1475.8 & 1676.5 & 1676.8 & 26.5 & 27.1 \\
\hline
\end{tabular}

Source: NIMET, Iseyin zonal office, Nigeria. 


\subsection{Field Experiments (2009 and 2010)}

\subsubsection{Weight of 100 Seeds as Affected by Variety and N Starter-Dose}

There was no significant difference in response of soybean to $\mathrm{N}$ starter doses in terms of weight of 100 seeds in Ipapo field of Iseyin soil series (Table 3). In Gbonran field of Sepeteri soil series, soybean responded differently to $\mathrm{N}$ doses in terms of weight of 100 seeds. The control treatment $(0 \mathrm{~kg} \mathrm{~N} / \mathrm{ha})$ produced the heaviest 100 seeds while $35 \mathrm{~kg} \mathrm{~N} / \mathrm{ha}$ dose produced the least 100 seeds weight (Table 4). Varietal responses were significantly different at both fields with variety TGx1448-2E producing heavier 100 seeds than those of TGx1485-1D on the average (Tables 3 and 4).

\subsubsection{Shoot N Accumulation as Affected by Variety and N Starter-Dose}

Soybean's response to $\mathrm{N}$ starter dose in terms of shoot $\mathrm{N}$ content was not significantly different across both locations (Gbonran and Ipapo fields). However, the two soybean varieties responded differently in Ipapo field where variety TGx1485-1D plants accumulated a significantly greater shoot $\mathrm{N}$ content than those of TGx1448-2E (Tables 3 and 4).

\subsubsection{Dry Shoot Weight (Biomass) as Affected by Variety and N Starter-Dose}

Soybean's dry shoot weight response to $\mathrm{N}$ starter dose was similar across both locations. However, response along soybean lines was significantly different in respect of dry shoot weight with variety TGx1485-1D plants having a significantly lesser dry shoot weight than those of TGx1448-2E (Tables 3 and 4). The interaction of N level $\mathrm{x}$ variety showed significantly different responses at 0,5 and $35 \mathrm{~kg} \mathrm{~N} / \mathrm{ha}$ application rates with variety TGx1448-2E producing higher dry shoot weight in Ipapo field at harvest (Figure 1), however, in Gbonran field, all $\mathrm{N}$ application rates except $5 \mathrm{~kg} \mathrm{~N} /$ ha produced significant factor interaction with TGx1448-2E showing dominance (Figure 2).

\subsubsection{Dry Seed Weight as Affected by Variety and N Starter-Dose}

There was a significant difference in varietal response to $\mathrm{N}$ starter doses in terms of dry seed weight across both locations (Tables 3 and 4). Variety TGx1448-2E produced a significantly higher dry seed weight than variety TGx1485-1D. With respect to $\mathrm{N}$ application rates, $25 \mathrm{~kg} / \mathrm{ha}$ dose produced the significantly higher dry seed weight than the control $(0 \mathrm{~kg} / \mathrm{ha})$; though not significantly different from all other doses in Ipapo field (Table 3). There was no significant response was observed in Gbonran field in terms of dry seed weight (Table 4).

\subsubsection{Harvest Index as Affected by Variety and N Starter-Dose}

There was a significant difference in varietal response in terms of harvest index with variety TGx1485-1D having a significantly higher harvest index than variety TGx1448-2E in both fields (Tables 3and 4). In terms of $\mathrm{N}$ application rates, $5 \mathrm{~kg} / \mathrm{ha}$ dose produced the significantly highest harvest index and the lowest harvest index was produced by zero N application (control) in Ipapo field (Table 3). In Gbonran field, there was no difference in response in terms of harvest index (Table 4).

\subsection{CROPGRO - Soybean Model}

\subsubsection{Soil Profile Description and Calibration}

The texture of the soil ranges from loamy sand at the top, becoming finer with depth to become sandy-clay loam (Table 5). The colour ranges from $7.5 \mathrm{YR} 4 / 3$ at the top to $2.5 \mathrm{YR} 5 / 6$ at the bottom of the profile. The bulk density of the soil is fairly normal, increasing from the top to the subsoil and later decreased down the profile. It ranges between $1.54-1.74 \mathrm{mg} / \mathrm{m}^{3}$. The overburden effect and the increasing clay content are primarily responsible for this observation, the saturated hydraulic conductivity of the horizons ranges from $0.264-0.469 \mathrm{~cm} \mathrm{hr}^{-1}$. 
Table 3. Effects of $\mathrm{N}$ dose and variety on yield and percent (\%) shoot $\mathrm{N}$ in Ipapo (2009-2010)

\begin{tabular}{|c|c|c|c|c|c|}
\hline Treatment & 100 seed weight (g) & $\%$ Shoot N & $\begin{array}{l}\text { Dry shoot weight } \\
\text { (kg/ha) }\end{array}$ & $\begin{array}{l}\text { Dry Seed weight } \\
(\mathrm{kg} / \mathrm{ha})\end{array}$ & Harvest Index \\
\hline \multicolumn{6}{|c|}{ Nitrogen Dose (kg/ha) } \\
\hline 0 & 24.72 & 3.05 & 2103 & 1241 & 0.59 \\
\hline 5 & 23.18 & 2.77 & 2145 & 1287 & 0.60 \\
\hline 15 & 23.97 & 3.17 & 2372 & 1376 & 0.58 \\
\hline 25 & 24.90 & 2.75 & 2398 & 1371 & 0.58 \\
\hline 35 & 25.75 & 2.90 & 2530 & 1342 & 0.57 \\
\hline $\operatorname{LSD}(0.05)$ & $4.11 \mathrm{~ns}$ & $0.480 \mathrm{~ns}$ & $439 \mathrm{~ns}$ & 118.5 & 0.02 \\
\hline \multicolumn{6}{|c|}{ Soyabean variety } \\
\hline TGx1485-1D & 21.73 & 3.29 & 2322 & 1347 & 0.58 \\
\hline TGx1448-2E & 27.28 & 2.56 & 2961 & 1540 & 0.52 \\
\hline $\operatorname{LSD}(0.05)$ & 2.75 & 0.42 & 521.2 & 147.2 & 0.012 \\
\hline
\end{tabular}

ns - not significant.

Table 4. Effects of $\mathrm{N}$ dose and variety on yield and percent (\%) shoot $\mathrm{N}$ in Gbonran (2009-2010)

\begin{tabular}{llllll}
\hline Treatment & 100 seed weight $(\mathrm{g})$ & $\%$ Shoot N & $\begin{array}{l}\text { Dry shoot weight } \\
(\mathrm{kg} / \mathrm{ha})\end{array}$ & $\begin{array}{l}\text { Dry Seed weight } \\
(\mathrm{kg} / \mathrm{ha})\end{array}$ & Harvest Index \\
\hline Nitrogen Dose $(\mathrm{kg} / \mathrm{ha})$ & & & 1095 & 0.51 \\
$0 \mathrm{~kg} \mathrm{~N} / \mathrm{ha}$ & 22.29 & 2.91 & 2441 & 1072 & 0.50 \\
$5 \mathrm{~kg} \mathrm{~N} / \mathrm{ha}$ & 19.87 & 2.56 & 2560 & 1080 & 0.47 \\
$15 \mathrm{~kg}$ N/ha & 19.62 & 2.89 & 2919 & 1095 & 0.45 \\
$25 \mathrm{~kg}$ N/ha & 20.00 & 2.33 & 3100 & 1070 & 0.47 \\
$35 \mathrm{~kg}$ N/ha & 19.62 & 2.78 & 3064 & $197 \mathrm{~ns}$ & $0.12 \mathrm{~ns}$ \\
LSD (0.05) & 1.67 & $0.94 \mathrm{~ns}$ & $1642 \mathrm{~ns}$ & & 0.58 \\
Soyabean variety & & & 1346 & 0.53 \\
TGx1485-1D & 16.67 & 2.81 & 2804 & 1539 & 0.03 \\
TGx1448-2E & 23.90 & 2.57 & 2903 & 136.9 & \\
LSD (0.05) & 1.48 & $0.43 \mathrm{~ns}$ & 93.4 & & \\
\hline
\end{tabular}

ns - not significant.

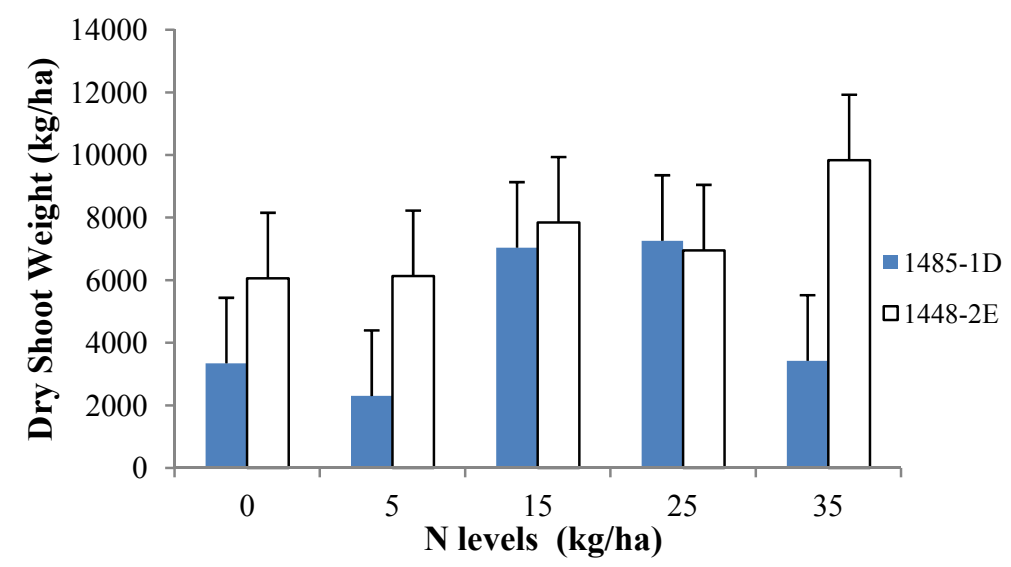

Figure 1. The effect of different $\mathrm{N}$ levels on dry shoot weight of soyabean at harvest in Ipapo field. Extensions on vertical bars represent $L S D$ at $p \leq 0.05$ 


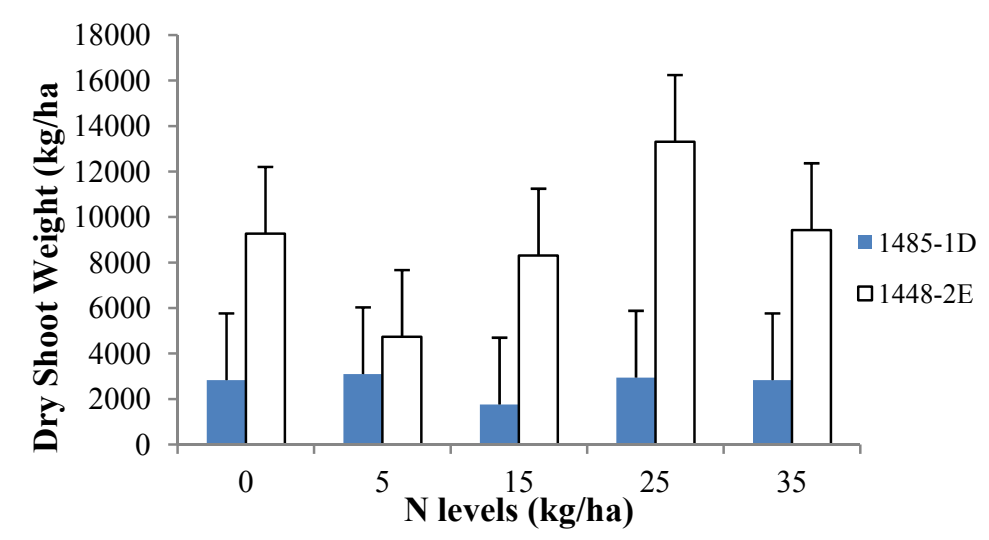

Figure 2. The effect of different $\mathrm{N}$ levels on dry shoot weight of soyabean at harvest in Gbonran field. Extensions on vertical bars represent LSD at $\mathrm{p} \leq 0.05$

The available moisture content generally increases with depth (Table 5) while the slope ranges from $2-6 \%$ at both locations. The soils have been classified locally as Iseyin and Sepeteri series (Murdoch et al., 1976) for Ipapo and Gbonran locations respectively. The chemical characteristics (Table 6) of the horizons revealed that soil acidity increases with depth, organic $\mathrm{C}$ and total $\mathrm{N}$ decrease down the profile in an irregular pattern. The soils are generally classified at higher category as ferric luvisols and ferric luvisol (Eutric) (FAO, 2006) or Arenic kanduistalf and plinthic kanduistalf (USDA, 2006) respectively for soils from Ipapo and Gbonran locations.

\subsubsection{Soybean Genetic Coefficient Determination}

The genetic coefficients (GC) are related to photoperiod and thermal time required to attain phenological events and dry matter accumulation. These coefficients allow the same soybean crop growth model to predict differences in the behavior of a single cultivar when planted in different environments (Boote et al., 1998). The GCs of the varieties were determined using the default DSSAT values as a starting point (Boote et al., 1997). The various default maturity groups were tried until a default maturity group (MG) that predicted the right total crop life cycle to maturity within 0 - 1day was obtained (Table 7).

\subsubsection{Crop Growth and Development Data}

In the first cropping season (2009), there was no difference in predicted and measured values for soybean phenology of variety TGx1485-1D with all $\mathrm{N}$ application rates except 1 day difference in the number of days to physiological maturity at $15 \mathrm{~kg} \mathrm{~N} / \mathrm{ha}$ application rate. Variety TGx1448-2E behaved similarly except for 1 day apiece in the number of days to first pod and physiological maturity at $5 \mathrm{~kg} \mathrm{~N} / \mathrm{ha}$ application rate in Ipapo field (Table 8). Similar results were observed in Gbonran field with 1 day variation at different $\mathrm{N}$ application rates for variety TGx1448-2E, however, no variation was observed for variety TGx1485-1D (Table 8). The second cropping season (2010) showed similar results with 1 day variation in soybean phenology at different $\mathrm{N}$ application rates in both fields (Table 9).

\subsubsection{Statisyical Analysis}

The RMSE and PE for soybean phenology (i.e. days to antheses, first pod, first seed and physiological maturity) for variety TGx1484-1D and TGx1448-2E were very low, ranging from $0-1.4 \%$ (Table10) indicating a very good prediction. The corresponding values for the yields revealed good prediction for the yield of variety TGx1485-1D ranging from $4.4-8.9 \%$ and poor prediction for the yields of TGx1448-2E with very high PE values ranging from $63.2-71.1 \%$ (Table 10 ).

\subsubsection{Soil Water Balance}

Drainage ranged from $8.9-11.4 \%$ of the total precipitation in 2009 while runoff ranged between 38.2 to $40.1 \%$ in both Ipapo and Gbonran fields (Tables 11). In the second cropping year (2010), drainage ranged from 3.5 - 7.4\% and runoff ranged from 43.1 to $44.8 \%$ in both fields respectively (Tables 12 ). 
Table 5. Physical and hydrological properties of the soil profiles in the study areas

\begin{tabular}{ccccccccccccc}
\hline $\begin{array}{c}\text { Depth } \\
(\mathrm{cm})\end{array}$ & SLMH & SLLL & SDUL & SSAT & SRGF & SSKS & SBDM & Clay & Silt & Sand & $\begin{array}{c}\text { Textural } \\
\text { Class }\end{array}$ & Colour \\
\hline Ipapo & & & & & & & & & & & & \\
$0-18$ & AP & 0.014 & 0.111 & 0.387 & 1.0 & 19.93 & 1.63 & 100 & 54 & 846 & LS & 7.5 YR4/3 \\
$18-66$ & BW & 0.017 & 0.110 & 0.295 & 1.0 & 6.31 & 1.74 & 460 & 54 & 486 & SC & 7.5 YR5/6 \\
$66-90$ & BW & 0.021 & 0.112 & 0.264 & 1.0 & 12.9 & 1.61 & 400 & 94 & 506 & SC & 7.5 YR5/8 \\
$90-128$ & BW & 0.016 & 0.113 & 0.407 & 0.6 & 2.01 & 1.64 & 320 & 74 & 606 & SCL & 7.5 YR4/6 \\
$128-150$ & BC & 0.098 & 0.117 & 0.469 & 0.0 & 1.77 & 1.54 & 320 & 74 & 606 & SCL & $2.5 Y R 5 / 6$ \\
Gbonran & & & & & & & & & & & & \\
$0-26$ & AP & 0.011 & 0.107 & 0.357 & -99 & 0.69 & 1.59 & 80 & 34 & 846 & LS & $7.5 Y R 4 / 3$ \\
$26-64$ & BW & 0.028 & 0.117 & 0.449 & -99 & 3.00 & 1.49 & 400 & 74 & 526 & SC & $7.5 Y R 5 / 8$ \\
$64-118$ & BW & 0.010 & 0.111 & 0.714 & -99 & 2.14 & 1.51 & 280 & 74 & 646 & SCL & 7.5 YR5/8, \\
$118-134$ & BW & 0.022 & 0.118 & 0.469 & -99 & 4.81 & 1.49 & 180 & 274 & 546 & SL & $7.5 Y R 4 / 6$, \\
134170 & BC & 0.078 & 0.121 & 0.376 & -99 & 54.4 & 1.24 & 360 & 94 & 546 & SC & $2.5 Y R 4 / 3$ \\
\hline
\end{tabular}

LS - Loamy sand; SC - Sandy clay; SL - Silty loam; SCL - Sandy clay loam; SLLL - Soil water lower limit (permanent wilting point); SDUL - Drained upper limit of soil (field capacity); SSAT - Soil saturation; SRGF Soil root growth factor; SSKS - Hydraulic conductivity; SBDM - Soil bulk density; -99 - Data not available.

Table 6. Chemical properties of the soils of the study area

\begin{tabular}{|c|c|c|c|c|c|c|c|c|c|c|c|c|c|c|c|}
\hline $\begin{array}{c}\text { Profile } \\
\text { depth }\end{array}$ & $\mathrm{pH}$ & TOC & $\mathrm{TN}$ & $\begin{array}{c}\text { Avail } \\
\text { P }\end{array}$ & $\begin{array}{c}\text { Ex. } \\
\text { Acidity }\end{array}$ & $\mathrm{Ca}$ & $\mathrm{Mg}$ & $\mathrm{Na}$ & K & CEC & B sat. & $\mathrm{Mn}$ & $\mathrm{Fe}$ & $\mathrm{Cu}$ & $\mathrm{Zn}$ \\
\hline \multicolumn{16}{|l|}{ Ipapo } \\
\hline $0-18$ & 6.66 & 5.04 & 0.52 & 20.20 & 0.6 & 2.54 & 0.62 & 0.31 & 0.12 & 3.58 & 85.64 & 40.7 & 9.8 & 2.19 & 1.27 \\
\hline $18-66$ & 5.82 & 5.81 & 0.60 & 7.40 & 0.3 & 4.06 & 1.23 & 0.31 & 0.10 & 5.70 & 95.00 & 12.7 & 11.5 & 0.93 & 0.36 \\
\hline $66-90$ & 5.64 & 5.04 & 0.53 & 3.63 & 0.6 & 4.44 & 1.35 & 0.31 & 0.09 & 6.18 & 91.15 & 50.6 & 55.9 & 0.68 & 0.59 \\
\hline $90-128$ & 5.62 & 5.04 & 0.52 & 5.17 & 1.4 & 3.64 & 1.39 & 0.44 & 0.13 & 5.59 & 79.98 & 4.1 & 14.2 & 0.36 & 0.39 \\
\hline $128-150$ & 5.63 & 2.33 & 0.24 & 3.16 & 0.6 & 4.86 & 1.32 & 0.43 & 0.14 & 6.76 & 91.85 & 6.4 & 20 & 0.37 & 0.35 \\
\hline \multicolumn{16}{|l|}{ Gbonran } \\
\hline $0-26$ & 6.71 & 20.92 & 2.16 & 17.73 & 0.3 & 7.66 & 1.04 & 0.44 & 0.25 & 9.38 & 96.9 & 76.1 & 9.1 & 1.13 & 1.26 \\
\hline $26-64$ & 6.00 & 10.46 & 1.08 & 11.10 & 0.3 & 4.37 & 1.23 & 0.26 & 0.20 & 6.06 & 95.28 & 38.6 & 9.6 & 1.11 & 0.52 \\
\hline $64-118$ & 5.71 & 1.55 & 0.16 & 5.55 & 0.3 & 3.36 & 1.24 & 0.30 & 0.24 & 5.15 & 94.49 & 19.9 & 12.5 & 0.26 & 0.97 \\
\hline $118-134$ & 5.64 & 5.04 & 0.52 & 1.54 & 1.6 & 4.24 & 1.07 & 0.31 & 0.18 & 5.79 & 78.35 & 11.8 & 11.7 & 0.22 & 0.6 \\
\hline $134-170$ & 5.60 & 5.04 & 0.53 & 2.24 & 0.4 & 3.08 & 1.05 & 0.31 & 0.11 & 4.55 & 91.92 & 3.6 & 12.7 & 0.40 & 0.39 \\
\hline
\end{tabular}

TOC - Total Organic Content; TN - Total Nitrogen; CEC - Cation Exchange Capacity; B. sat - Base saturation. 
Table 7. Modified genetic coefficients for soybean varieties used

\begin{tabular}{|c|c|c|c|c|}
\hline Parameter & Definition & Unit & Tgx1485-1d & $\operatorname{Tgx} 1448-2 \mathrm{e}$ \\
\hline Em-F1 & Time between plant emergence and flower emergence (R1) & Ptd & 13.09 & 11.88 \\
\hline Fl-Sh & Time between first flower and first pod (R3) & Ptd & 0.29 & 0.34 \\
\hline Fl-Sd & Time between first flower and first seed (R5) & Ptd & 25.00 & 28.90 \\
\hline Sd-Pm & Time between first seed (R5) and physiological maturity (R7) & Ptd & 9.00 & 7.00 \\
\hline Fl-Lf & Time between first flower (R1) and the end of leaf expansion & Ptd & 13.80 & 13.50 \\
\hline Slavr & Specific leaf area of cultivar under standard growth conditions & $\mathrm{Cm}^{2} \mathrm{~g}^{-1}$ & 30.00 & 31.50 \\
\hline Sizlf & Maximum size of full leaf (Three Leaflets) & $\mathrm{Cm}^{2}$ & 25.00 & 15.00 \\
\hline Wtpsd & Maximum weight per seed & G & 1.00 & 1.03 \\
\hline Csdl & $\begin{array}{l}\text { Critical short day length below which reproductive development progresses } \\
\text { with no day-length effect (for short day plant) }\end{array}$ & $\mathrm{Hr}$ & 300.00 & 300.00 \\
\hline Ppsen & $\begin{array}{l}\text { Slope of the relative response of development to photoperiod with time } \\
\text { (positive for short-day plants) }\end{array}$ & $\mathrm{L} / \mathrm{Hr}$ & 190.00 & 180.00 \\
\hline Lfmax & Maximum leaf photosynthesis rate at $30^{\circ} \mathrm{C}, 350 \mathrm{Vpm} \mathrm{CO}_{2}$ and high light & $\begin{array}{l}\mathrm{Mg} \\
\mathrm{Co}_{2} \mathrm{~m}^{-2} \mathrm{~s}^{-1}\end{array}$ & 1.00 & 1.00 \\
\hline Xfrt & Maximum fraction of daily growth that is partitioned to seed + shell & & 0.19 & 0.18 \\
\hline Sfdur & Seed filling duration for pod cohort at standard growth conditions & Ptd & 25.50 & 22.00 \\
\hline Sdpdv & Average seed per pod under standard growth conditions & \#/Pod & 2.40 & 2.05 \\
\hline Podur & Time required for cultivar to reach final pod load under optimal conditions & Ptd & 10.50 & 10.00 \\
\hline
\end{tabular}

PTD - Photothermal days. 
Table 8. Comparison of selected field observation and their simulation in Ipapo and Gbonran 2009

\begin{tabular}{|c|c|c|c|c|}
\hline \multirow[t]{2}{*}{ Variable } & \multicolumn{2}{|c|}{ TGx1485-1D } & \multicolumn{2}{|c|}{ TGx1448-2E } \\
\hline & Simulated & Measured & Simulated & Measured \\
\hline \multicolumn{5}{|l|}{ No $\mathrm{N}$ application } \\
\hline Anthesis day (dap) & 33 & 33 & 44 & 44 \\
\hline First pod day (dap) & 43 & 43 & 56 & 55 \\
\hline First seed day (dap) & 49 & 49 & 67 & 67 \\
\hline Physiol. Mat. day (dap) & 79 & 79 & 102 & 101 \\
\hline Yield at harvest mat. $(\mathrm{kg}[\mathrm{dm}] / \mathrm{ha}$ & 1659.5 & 1523 & 1769.5 & 1661 \\
\hline \multicolumn{5}{|l|}{$5 \mathrm{~kg} \mathrm{~N}$ application } \\
\hline Anthesis day (dap) & 33 & 33 & 44 & 44 \\
\hline First pod day (dap) & 43 & 43 & 56 & 56 \\
\hline First seed day (dap) & 49 & 49 & 67 & 67 \\
\hline Physiol. Mat. day (dap) & 79 & 80 & 102 & 102 \\
\hline Yield at harvest mat. $(\mathrm{kg}[\mathrm{dm}] / \mathrm{ha}$ & 1661.5 & 1556 & 1771 & 1694 \\
\hline \multicolumn{5}{|l|}{$15 \mathrm{~kg} \mathrm{~N}$ application } \\
\hline Anthesis day (dap) & 33 & 33 & 44 & 44 \\
\hline First pod day (dap) & 43 & 43 & 56 & 56 \\
\hline First seed day (dap) & 49 & 49 & 67 & 67 \\
\hline Physiol. Mat. day (dap) & 79 & 79 & 102 & 101 \\
\hline Yield at harvest mat. $(\mathrm{kg}[\mathrm{dm}] / \mathrm{ha}$ & 1658 & 1544.5 & 1770.5 & 1685.5 \\
\hline \multicolumn{5}{|l|}{$25 \mathrm{~kg} \mathrm{~N}$ application } \\
\hline Anthesis day (dap) & 33 & 33 & 44 & 44 \\
\hline First pod day (dap) & 43 & 43 & 56 & 56 \\
\hline First seed day (dap) & 49 & 49 & 67 & 67 \\
\hline Physiological maturity day (dap) & 79 & 79 & 102 & 102 \\
\hline Yield at harvest maturity $(\mathrm{kg}[\mathrm{dm}] / \mathrm{ha}$ & 1652 & 1573.5 & 1772.5 & 1718 \\
\hline \multicolumn{5}{|l|}{$35 \mathrm{~kg} \mathrm{~N}$ application } \\
\hline Anthesis day (dap) & 33 & 34 & 44 & 44 \\
\hline First pod day (dap) & 43 & 44 & 56 & 56 \\
\hline First seed day (dap) & 49 & 49 & 67 & 67 \\
\hline Physiological maturity day (dap) & 79 & 79 & 102 & 103 \\
\hline Yield at harvest mat. $(\mathrm{kg}[\mathrm{dm}] / \mathrm{ha}$ & 1661.5 & 1590.5 & 1781 & 1735.5 \\
\hline
\end{tabular}

dap - days after planting. 
Table 9. Comparison of selected field observation and their simulation in Ipapo and GBonran 2010

\begin{tabular}{|c|c|c|c|c|}
\hline \multirow[t]{2}{*}{ Variable } & \multicolumn{2}{|c|}{ TGx1485-1D } & \multicolumn{2}{|c|}{ TGx1448-2E } \\
\hline & Simulated & Measured & Simulated & Measured \\
\hline \multicolumn{5}{|l|}{ No $\mathrm{N}$ application } \\
\hline Anthesis day (dap) & 32 & 32 & 44 & 44 \\
\hline First pod day (dap) & 43 & 42 & 57 & 57 \\
\hline First seed day (dap) & 48 & 48 & 68 & 67 \\
\hline Physiol. Mat. day (dap) & 79 & 78 & 112 & 111 \\
\hline Yield at harvest mat. $(\mathrm{kg}[\mathrm{dm}] / \mathrm{ha}$ & 1267.5 & 1168 & 3311 & 1649.5 \\
\hline \multicolumn{5}{|l|}{$5 \mathrm{~kg} \mathrm{~N}$ application } \\
\hline Anthesis day (dap) & 32 & 32 & 44 & 44 \\
\hline First pod day (dap) & 43 & 43 & 57 & 57 \\
\hline First seed day (dap) & 48 & 48 & 68 & 67 \\
\hline Physiol. Mat. day (dap) & 79 & 79 & 112 & 111 \\
\hline Yield at harvest mat. $(\mathrm{kg}[\mathrm{dm}] / \mathrm{ha}$ & 1247.5 & 1179.5 & 3320 & 1711.5 \\
\hline \multicolumn{5}{|l|}{$15 \mathrm{~kg} \mathrm{~N}$ application } \\
\hline Anthesis day (dap) & 32 & 32 & 44 & 44 \\
\hline First pod day (dap) & 43 & 43 & 57 & 57 \\
\hline First seed day (dap) & 48 & 48 & 68 & 68 \\
\hline Physiol. Mat. day (dap) & 79 & 79 & 112 & 111 \\
\hline Yield at harvest mat. $(\mathrm{kg}[\mathrm{dm}] / \mathrm{ha}$ & 1264 & 1228 & 3323.5 & 1753 \\
\hline \multicolumn{5}{|l|}{$25 \mathrm{~kg} \mathrm{~N}$ application } \\
\hline Anthesis day (dap) & 32 & 32 & 44 & 44 \\
\hline First pod day (dap) & 43 & 43 & 57 & 58 \\
\hline First seed day (dap) & 48 & 48 & 68 & 68 \\
\hline Physiological maturity day (dap) & 79 & 80 & 112 & 111 \\
\hline Yield at harvest maturity $(\mathrm{kg}[\mathrm{dm}] / \mathrm{ha}$ & 1273 & 1233 & 3338.5 & 1759.5 \\
\hline \multicolumn{5}{|l|}{$35 \mathrm{~kg} \mathrm{~N}$ application } \\
\hline Anthesis day (dap) & 32 & 31 & 44 & 44 \\
\hline First pod day (dap) & 43 & 44 & 57 & 58 \\
\hline First seed day (dap) & 48 & 49 & 68 & 68 \\
\hline Physiological maturity day (dap) & 79 & 80 & 112 & 112 \\
\hline Yield at harvest mat. $(\mathrm{kg}[\mathrm{dm}] / \mathrm{ha}$ & 1269 & 1206 & 3368 & 1792 \\
\hline
\end{tabular}

dap-days after planting. 
Table 10. RMSE and PE for soybean varieties

\begin{tabular}{lllllllllll}
\hline \multirow{2}{*}{ TRT } & \multicolumn{2}{c}{ Anthesis } & \multicolumn{2}{c}{ DFP } & \multicolumn{2}{c}{ DFS } & \multicolumn{2}{c}{ DPM } & \multicolumn{2}{c}{ Yield (kg dm/ha) } \\
\cline { 2 - 10 } & RMSE & PE (\%) & RMSE & PE (\%) & RMSE & PE (\%) & RMSE & PE (\%) & RMSE & PE (\%) \\
\hline \multicolumn{2}{l}{ Variety TGx 1485-1D } & & & & & & & & \\
0 & 0.0 & 0.0 & 0.0 & 0.0 & 0.0 & 0.0 & 0.7 & 0.9 & 119.4 & 8.9 \\
5 & 0.0 & 0.0 & 0.0 & 0.0 & 0.0 & 0.0 & 0.7 & 0.9 & 88.8 & 6.8 \\
15 & 0.0 & 0.0 & 0.0 & 0.0 & 0.0 & 0.0 & 0.0 & 0.0 & 84.2 & 6.1 \\
25 & 0.0 & 0.0 & 0.0 & 0.0 & 0.0 & 0.0 & 0.7 & 0.9 & 62.3 & 4.4 \\
35 & 0.0 & 0.0 & 0.0 & 0.0 & 0.7 & 1.4 & 0.7 & 0.9 & 67.1 & 4.8 \\
Variety TGx1448-2E & & & & & & & & \\
0 & 0.0 & 0.0 & 0.7 & 1.3 & 0.7 & 1.1 & 1.0 & 0.9 & 1177.4 & 71.1 \\
5 & 0.0 & 0.0 & 0.0 & 0.0 & 0.7 & 1.1 & 0.7 & 0.7 & 1138.7 & 66.9 \\
15 & 0.0 & 0.0 & 0.0 & 0.0 & 0.0 & 0.0 & 1.0 & 0.9 & 1112.1 & 64.7 \\
25 & 0.0 & 0.0 & 0.7 & 1.2 & 0.0 & 0.0 & 0.7 & 0.7 & 1117.2 & 64.3 \\
35 & 0.0 & 0.0 & 0.7 & 1.2 & 0.0 & 0.0 & 0.7 & 0.7 & 1114.9 & 63.2 \\
\hline
\end{tabular}

RMSE - Root square mean error; PE - Percentage error; TRT - Treatments in kg N/ha; DFP - Days to first pod; DFS - Days to fist seed; DPM - Days to physiological maturity.

Table 11. Soil water balance (Ipapo and Gbonran), 2009

\begin{tabular}{|c|c|c|c|c|c|c|c|c|c|c|}
\hline \multirow{3}{*}{ Parameters } & \multicolumn{10}{|c|}{$\mathrm{N}$ application rate $(\mathrm{kg} / \mathrm{ha})$} \\
\hline & \multicolumn{2}{|c|}{0} & \multicolumn{2}{|c|}{5} & \multicolumn{2}{|c|}{15} & \multicolumn{2}{|c|}{25} & \multicolumn{2}{|c|}{35} \\
\hline & $\mathrm{mm}$ & $\%$ & $\mathrm{~mm}$ & $\%$ & $\mathrm{~mm}$ & $\%$ & $\mathrm{~mm}$ & $\%$ & $\mathrm{~mm}$ & $\%$ \\
\hline \multicolumn{11}{|l|}{$\underline{\text { TGx } 1485-1 \mathrm{D}}$} \\
\hline Precipitation & 521.9 & 100.0 & 521.9 & 100.0 & 521.9 & 100.0 & 521.9 & 100.0 & 521.9 & 100.0 \\
\hline Drainage & $52.9-59.6$ & $10.0-11.4$ & $52.3-59.6$ & $10.0-1.4$ & $52.3-59.7$ & $10.0-11.4$ & $52.3-59.7$ & $10.0-11.4$ & $52.3-59.7$ & $10.0-11.4$ \\
\hline Runoff & $201.9-201.2$ & 38.7 & $201.9-202.2$ & 38.7 & $201.9-02.2$ & 38.7 & $201.9-202.2$ & 38.7 & $201.9-202.2$ & 38.7 \\
\hline Transpiration & $104.5-106.8$ & $20.0-20.5$ & $104.2-107.3$ & $20.0-0.5$ & 104.3-107 & $20.0-20.5$ & 104.4-107 & $20.0-20.5$ & $104.7-107.2$ & $20.1-20.5$ \\
\hline \multicolumn{11}{|l|}{$\underline{\mathrm{TG}} 1448-2 \mathrm{E}$} \\
\hline Precipitation & $550.1-592.0$ & 100.0 & $550.1-92.0$ & 100.0 & 550.1592 .0 & 100.0 & $550.1-592$ & 100.0 & $550.1-592$ & 100.0 \\
\hline Drainage & $52.3-59.8$ & $8.9-10.9$ & $52.5-59.8$ & 8.9-10.9 & $52.5-60.7$ & $8.9-11.0$ & $52.5-60.7$ & $8.9-11.0$ & $52.5-60.7$ & 8.9-11.0 \\
\hline Runoff & $210.3-238.6$ & $38.2-40.1$ & $210.4-237.6$ & $38.2-40.1$ & $210.4-237.6$ & $38.2-40.1$ & 210.4-237.6 & $38.2-40.1$ & $210.4-237.6$ & $38.2-40.1$ \\
\hline Transpiration & $145.5-147.2$ & $24.6-26.8$ & $145.7-148.0$ & $24.6-26.9$ & $145.9-147.9$ & $24.6-26.4$ & $146.0-147.9$ & $24.7-26.9$ & $146.7-148.2$ & $24.8-26.9$ \\
\hline
\end{tabular}

$\%$ - Percentage contribution to water balance. 
Table 12. Soil water balance (Ipapo and Gbonran), 2010

\begin{tabular}{|c|c|c|c|c|c|c|c|c|c|c|}
\hline \multirow{3}{*}{ Parameters } & \multicolumn{10}{|c|}{$\mathrm{N}$ application rate $(\mathrm{kg} / \mathrm{ha})$} \\
\hline & \multicolumn{2}{|c|}{0} & \multicolumn{2}{|c|}{5} & \multicolumn{2}{|c|}{15} & \multicolumn{2}{|c|}{25} & \multicolumn{2}{|c|}{35} \\
\hline & $\mathrm{mm}$ & $\%$ & $\mathrm{~mm}$ & $\%$ & $\mathrm{~mm}$ & $\%$ & $\mathrm{~mm}$ & $\%$ & $\mathrm{~mm}$ & $\%$ \\
\hline \multicolumn{11}{|l|}{$\underline{T G x 1485-1 D}$} \\
\hline Precipitation & 510 & 100 & 510 & 100 & 510 & 100 & 510 & 100 & 510 & 100 \\
\hline Drainage & $29.5-37.9$ & $5.8-7.4$ & $29.2-37.8$ & $5.7-7.4$ & $29.3-37.8$ & $5.7-7.4$ & $29.5-37.8$ & $5.8-7.4$ & $29.5-37.9$ & $5.8-7.4$ \\
\hline Runoff & $220.1-220.4$ & $43.1-43.2$ & $220.1-220.4$ & $43.1-43.2$ & $220.1-220.4$ & $43.1-43.2$ & $220.1-220.4$ & $43.1-43.2$ & $220.1-220.4$ & $43.1-43.2$ \\
\hline Transpiration & $103.7-110.6$ & $20.3-21.6$ & $104.4-111.0$ & $20.5-21.7$ & $104.0-111.2$ & $20.4-21.8$ & $103.6-111.4$ & $20.3-21.8$ & $102.0-110.7$ & $20.0-21.8$ \\
\hline \multicolumn{11}{|l|}{$\underline{\mathrm{TGx} 1448-2 \mathrm{E}}$} \\
\hline Precipitation & 808.1 & 100.0 & 808.1 & 100.0 & 808.1 & 100.0 & 808.1 & 100.0 & 808.1 & 100.0 \\
\hline Drainage & $28.0-37.3$ & $3.5-4.6$ & $28.1-37.2$ & $3.5-4.6$ & $28.1-37.0$ & $3.5-4.6$ & $28.1-37.0$ & $3.5-4.6$ & $28.0-36.9$ & $3.5-4.6$ \\
\hline Runoff & $361.4-362$ & $44.7-44.8$ & $361.4-362$ & $44.7-44.8$ & $361.5-362$ & $44.7-44.8$ & $361.5-362$ & $44.7-44.8$ & $361.5-362$ & $44.7-44.8$ \\
\hline Transpiration & $213.4-220.6$ & $26.4-27.3$ & $214.2-220.8$ & $26.4-27.3$ & 213.4-221.6 & $26.4-27.3$ & 214.4-221.9 & $26.4-27.3$ & $214.8-222.6$ & $26.4-27.3$ \\
\hline
\end{tabular}

$\%$ - Percentage contribution to water balance.

\section{Discussion}

The soils of the study area were low in nutrients. The total N, available $\mathrm{P}$, exchangeable $\mathrm{K}$ and the organic matter were low. The top-soils are characteristically loamy sands, having over $80 \mathrm{~g} / \mathrm{kg}$ and component in texture. This intrinsic property makes the soil porous and hence devoid of colloidal materials or surfaces on which plant nutrients can adhere to (i.e. low nutrient retention capacity). It also affects the water holding capacity of the soil and consequently affects the growth and development of soybean. The mopping of native soil nitrogen further impoverished the soils so that the effects of the treatments could be easily monitored on soybean planted. The climatic/meteorological data of the area indicated that the area witnessed heavy rains early in 2009 and 2010 cropping seasons. The planting of soybean towards end of June in 2009 coincided with a period of heavy downpour. The rainfall amount peaked in July, during which time fertilizer application was made. At this period, rainfall amount far exceeded the potential evapo-transpiration, leaving the soil saturated with moisture, thus making the fertilizer amenable to quick dissolution and leaching/runoff losses because of intense rainfall events. During the 2010 cropping season, however, the rain started earlier and was with greater intensity and amount. The cropping season also witnessed a heavy downpour with a short spell towards August ending which was not long enough to give soybean a moisture stress. As a result of rainfall amount and intensity, fertilizer applied seven days after planting was not effectively utilized because the soils were saturated with moisture, thereby making the fertilizer material (urea) which is water-soluble, amenable to leaching and erosion losses.

The weight of 100 seeds is an important yield contributing component. It reflects the magnitude of seed development which ultimately reflects the final yield of the crop. In Gbonran field, soyabean responded differently to nitrogen doses in terms of weight of 100 seeds. The observed inverse relationship between seed weight and nitrogen doses revealed that nitrogen application favoured vegetative growth and by extension, seems to hinder seed yield. This result was in contrast to the work of Taylor et al. (2005) and Mehmet (2008) which showed that as nitrogen level increases, there was increase in weight of 100 seeds. It was also reported that 100 seeds weight is not affected by nitrogen application (Barker \& Sawyer, 2005) as observed in Ipapo field. The two soybean varieties also responded differently in terms of weight of 100 seeds in Ipapo field with TGx1448-2E producing 30\% heavier seeds than TGx1485-1D. This could be ascribed to the genetic composition of the varieties.

Response to nitrogen application in terms of shoot $\mathrm{N}$-content was also similar but the varieties responded differently, with variety TGx1485-1D plants accumulating more nitrogen in shoot than those of TGx1448-2E. The difference in the response of soybean varieties to shoot $\mathrm{N}$ accumulation could also be ascribed to the genetic make-up of the varieties.

The response of soybean in terms of dry shoot weight to various nitrogen rates were similar, although, dry shoot weight of soybean increased as nitrogen rates increased. Similar report was given by Manral and Saxena (2003) 
who posited that soybean dry matter accumulation increased with nitrogen rates. The two varieties responded differently with variety TGx1448-2E plants producing heavier dry shoot than those of TGx1485-1D. This could be ascribed to the genetic make-up of the varieties.

The seed yield response of soybean to nitrogen application varied. While nitrogen rates did not influence seed yield across all nitrogen rates applied in Sepeteri series soils of Gbonran field, positive effects were observed in Iseyin soil series of Ipapo field. Similar results were reported in some field investigations (Startling et al., 1998; Taylor et al., 2005; Osborne \& Riedell, 2006). There was varietal response to soils from both locations. This is in agreement with earlier works by Okpara and Ibiam (2000) as well as Yusuf and Idowu (2001) who observed significant differences among soybean cultivars.

Harvest index is a measure of conversion of plant total dry matter to yield. It is the partitioning of assimilated photosynthate to the seed. The application of nitrogen rates resulted in marked differences in soybean response in terms of harvest index in Ipapo field. There was no such response observed in Gbonran field, but the two varieties responded differently with variety TGx1485-1D having a significantly higher index than TGx1448-2E. This revealed that variety TGx1485-1D is more efficient in converting assimilated photosynthate to seeds. It is also a function of the genetic composition of the variety.

Although soybean response to nitrogen fertilization has been studied extensively; while some researchers reported positive responses, others reported negative responses (Salvagiotti et al., 2008). The finding of this work revealed that starter nitrogen dose has little or no effect on the performance of soybean in the study area. This is in line with works by Hoeft et al. (2000) and Heatherly et al. (2003) whose reports have indicated that in most cases, soybean grown on most soils does not respond to low rates of starter nitrogen. The variation in the effects of nitrogen starter-doses, to a large extent, depended on native soil fertility. The crucial concern is to reach the minimal soil fertility level required for good soybean growth and performance. High yielding soybean varieties such as TGx1485-1D and TGx1448-2E require enough $\mathrm{P}$ and also a starter dose of nitrogen for proper establishment because soils in the southern savanna zone of Nigeria have low fertility level. For instance, soils in both locations had very low $\mathrm{P}$ values (below the critical value of $15 \mathrm{mg} \mathrm{P} \mathrm{kg}^{-1}$ soil). Even though soybean can acquire $\mathrm{P}$ in the soil through other mechanisms, the roots of plants dependent on BNF had been reported to have a higher concentration of $P$ than those supplied with nitrate (Breeze \& Hopper, 1987). The N benefit of grain legumes to the soil depend on the N-fixing capability of the legumes and the native fertility of the soil (Sanginga et al., 1997). The quantification of the contribution of BNF to crop yield in this study is missing because the percentage of $\mathrm{N}$ fixed contained in the roots and nodules is outside the scope of this study and has not been accounted for.

Consequent upon variability in rainfall pattern, especially rainfall distribution/amount and in order to further understand the underlying factors responsible for the performance of soybean in the study region, DSSAT model, CROPGRO-Soybean, was employed to test the reliability of measured data and to unravel the dynamics of activities that occurred within the soil system as a result of nitrogen fertilizer application in the face of the prevailing weather conditions. The results clearly demonstrated that the cropping system model (CROPGRO-soybean) simulated soybean phenology quite well for both varieties studied, but poorly for the yields of variety TGx1448-2E. The RMSE is a measure of the difference between the predicted and the observed values, but provides no information on the relative size of the average difference between the predicted and measured values; hence it was expressed as a percentage error of means of observations (PE). The measured and simulated phenological data differed by not more than 1 day on the average, which is far less than $10 \%$ in $\mathrm{PE}$ values for the number of days to anthesis, first pod, first seed and physiological maturity and yields of variety TGx1485-1D under different $\mathrm{N}$ application rates. This is an indication that the measured data were very reliable for these phenological parameters with the cumulative reliability index ranking of $15 \mathrm{~kg} \mathrm{~N} / \mathrm{ha}>5 \mathrm{~kg} \mathrm{~N} / \mathrm{ha}>25$ $\mathrm{kg} \mathrm{N} / \mathrm{ha}>0 \mathrm{~kg} \mathrm{~N} / \mathrm{ha}>35 \mathrm{~kg} \mathrm{~N} / \mathrm{ha}$. There were very high differences (with high PE values) between the simulated and measured yield values of variety TGX1448-2E. Thus, the model prediction of the phenological data was very good for both varieties, but the model prediction of the yield for variety TGx1448-2E was bad. The poor yield prediction by DSSAT model according to Banterng et al. (2004) was that the model design did not take into cognizance the effects of pests and diseases, hence contributing to the model's over-estimation of yield values. The soil water balance output of the model revealed that runoff fell within about 39 to $41 \%$ in 2009, and in 2010, runoff accounted for between about 43 to $45 \%$ of the rainfall received during the cropping season. This implied that there was likelihood of dissolution and movement of mobile nutrients (especially from urea) during the cropping season and hence, is unavailable during the crucial time (Buman et al., 2004; Babalola et al., 2007). The deep drainage losses ranged from $3.5 \%$ in 2010 to $11 \%$ in 2009 of the total rainfall during the cropping seasons. This indicated that, although, some losses were from drainage, the bulk of the losses were through 
runoff. Hence, any conservation that would preserve water and prevent runoff will probably improve the N-use efficiency of soybean in these fields. The adoption of an efficient soil tillage and water conservation practices geared towards the reduction of runoff and conservation of the soil and water such as minimum tillage and mulching would improve soil-water-nutrient retention for crop growth and development (Thierfelder et al., 2005) Variety TGx1448-2E also utilized more water for its transpiration processes, an activity closely related to plant growth and biomass production, and this was responsible for its higher dry matter or biomass production.

\section{Conclusion}

The findings of this work revealed that starter nitrogen dose has little or no effect on the performance of soybean in the study areas. There were varietal differences between the two soybean varieties in response to the soil and climatic conditions of the southern guinea savanna agro-ecology of Oyo State, Nigeria. Variety TGx1485-1D exhibited varietal supremacy in terms of shoot $\mathrm{N}$ accumulation and seed production while variety TGx1448-2E exhibited dominance in terms of biomass production. Although, variety TGx1448-2E exhibited a better performance than TGx1485-1D in the study areas, variety TGx1485-1D would be a better variety in environment of less water availability such as the dry regions of the northern guinea savanna agro-ecology of Nigeria. The difference between the two soybean varieties studied showed that soybean has a broad genetic base with tremendous variability, which can be utilized by plant breeders for improving soybean production in this agro-ecology.

The CROPGRO-Soybean model accurately predicted days to anthesis, first pod, first seed and physiological maturity with very low PE values, hence the model's prediction was excellent and could be used to gauge the performance of soybean varieties under different environmental conditions. Nitrogen application rates exhibited a reliability index ranking of $15 \mathrm{~kg} \mathrm{~N} / \mathrm{ha}>5 \mathrm{~kg} \mathrm{~N} / \mathrm{ha}>0 \mathrm{~kg} \mathrm{~N} / \mathrm{ha}>25 \mathrm{~kg} \mathrm{~N} / \mathrm{ha}>35 \mathrm{~kg} \mathrm{~N} / \mathrm{ha}$ with CROPGRO-soybean model.

Although, some $\mathrm{N}$ losses were from deep drainage, the bulk of the losses were through runoff, accounting for about $45 \%$ of the total cropping season rainfall in the two seasons studied. Hence, any conservation that would preserve water and prevent runoff would improve the $\mathrm{N}$-use efficiency of starter $\mathrm{N}$ application to soybean in these fields.

\section{References}

Adamu, R. S., \& Amatobi, C. I. (2001). Field Evaluation of soybean genotypes for susceptibility to stinkbug damage at Samaru, Zaria. Tropical Oilseeds Journal, 7, 74-83.

Allen, E. M., Batchelor, W. D., \& Colvin, T. S. (1996). Validation of corn and soybean models in Iowa: Implications for precision farming (pp. 96-106). ASAE, St. Joseph, MI. ASAE.

Babalola, O., Oshunsanya, S. O., \& Are, K. (2007). Effects of Vetiver grass (V. nigritana) strips, vetiver grass mulch and an organic-mineral fertilizer on soil, water and nutrient losses and maize (Zea mays L) yield. Soil and Tillage Research, 96, 6-18. http://dx.doi.org/10.1016/j.still.2007.02.008

Banterng, P., Patanothai, A., Pannangpetch, K., Jogloy, S., \& Hoogenboom, G. (2004). Determination of genetic coefficients for peanut lines for breeding applications. European Journal of Agronomy, 21, 297-310. http://dx.doi.org/10.1016/j.eja.2003.10.002

Barker, D. W., \& Sawyer, J. E. (2005). Nitrogen application to soyabean at early reproductive development. Agronomy Journal, 97, 615-619. http://dx.doi.org/10.2134/agronj2005.0615

Boote, K. J., \& Tollenaar, M. (1994). Modeling genetic yield potential. In K.J. Boote et al. (Eds.), Physiology and determination of crop yield (pp. 533-565). ASA, CSSA and SSSA, Madison, WI. http://dx.doi.org/10.2134/1994.physiologyanddetermination.c34

Boote, K. J., Jones, J. W., \& Hoogenboom, G. (1998). Simulation of crop growth: GROPGRO model. In R. M. Peart \& R. B. Curry (Eds.), Agricultural Systems Modeling and Simulations (pp. 651-692). Marcel Decker Inc., New York.

Boote, K. J., Jones, J. W., Hoogenboom, G., \& Wilkerson, G. G. (1997). Evaluation of the GROPGRO-Soybean model over a wide range of experiments. In Kropff et al. (Eds.), Systems approaches for sustainable agricultural development: Application of systems approaches at the field level (pp. 113-133). Kluwer Academic Publ., Boston. http://dx.doi.org/10.1007/978-94-017-0754-1_8

Breeze, V. G., \& Hopper, M. J. (1987). The uptake of phosphate by plants from flowing nutrient solution. Journal of Experimental Botany, 38, 618-630. http://dx.doi.org/10.1093/jxb/38.4.618 
Buman, R. A., Alesii, B. A., Hatfield, J. L., \& Karlen, D. L. (2004). Profit, yield and soil quality effects on tillage systems in corn-soybean rotations. Journal of Soil and Water Conservation, 59(6), 260-270.

Curry, R. B., Jones, J. W., Boote, K. J., Pearl, R. M., Allen, L. H., \& Pickering, N. B. (1995). Response of soybean to predicted climate change in the USA. In C. Rosenzweig et al. (Eds.), Climate change and agriculture: Analysis of potential international impacts (pp. 163-182). ASA Spec. Publ.59 ASA, Madison, WI.

Egli, D. B., \& Bruening, W. (1992). Planting date and soybean yield: Evaluation of environmental effects with a crop simulation model, SOYGRO. Agricultural and Forest Meteorology, 62, 19-29. http://dx.doi.org/10.1016/0168-1923(92)90003-M

FAOSTAT. (2005). Food and Agricultural Organization (FAO) Statistical Yearbook.

Food and Agricultural Organization. (1988). FAO-UNESCO Soil map of the World, Revised Legend. World Soil Resources Report 60. FAO, Rome.

Food and Agricultural Organization. (2006). World Reference Base for Soil Resources. A Framework for International Classification, Correlation and Communication. Bulletin Report (No. 103, p. 130). FAO, Rome.

Genstat. (1995). Genstat 5 Release 3.2 for Windows 95 (p. 147). Lawes Agricultural Trust, Rothamstead Experimental Station, U.K.

Heatherly, L. G., Spurlock, S. R., \& Reddy, K. N. (2003). Influence of early-season nitrogen and weed management on irrigated and non-irrigated glyphosate-resistant and susceptible soybean. Agronomy Journal, 95, 446-453. http://dx.doi.org/10.2134/agronj2003.0446

Hoeft, R. G., Nafziger, E. D., Johnson, R. R., \& Aldrich, S. R. (2000). Modern corn and soybean production (1st Ed., p. 353). Modern Corn and Soybean Production (MCSP) Publications, Champaign, IL.

Hoogenboom, G., Wilkens, P. W., Thornton, P. K., Jones, J. W., Hunt, L. A., \& Imamura, D. T. (1999). Decision support system for agrotechnology transfer v3.5. In G. Hoogenboom, P. W. Wilkens \& G. Y. Tsuji (Eds.), DSSAT (Version 3, Vol. 4, pp. 1- 36, ISBN 1-886684-04-9). University of Hawaii, Honolulu, HI.

IBSNAT. (1998). DSSAT information page. Retrieved from http://www.icasanet.org/dssat/index_html

Jones, J. W., Keating, B. A., \& Porter, C. H. (2001). Approaches to modular model development. Agricultural Systems, 70, 421-443. http://dx.doi.org/10.1016/S0308-521X(01)00054-3

Manral, H. S., \& Saxena, S. C. (2003). Plant growth, yield attributes and grain yield of soyabean as affected by the application of inorganic and organic sources of nutrients. Bioresource Technology, 92, 110-118.

Mavromatis, T., Boote, K. J., Jones, J. W., Irmak, A., Shinde, D., \& Hoogenboom, G. (2001). Developing genetic coefficients for crop simulation models using data from crop performance trials. Crop Science, 41, 40-51. http://dx.doi.org/10.2135/cropsci2001.41140x

Mehmet, O. Z. (2008). Nitrogen rate and plant population effects on yield and yield component in soybean. African Journal of Biotechnology, 7(24), 4464-4470.

Murdoch, G., Ojo-Atere, J., Colborne, G., Olomu, E., \& Odugbesan, E. (1976). Soils of Western State Savannah Land. Research Study 23, Vol. 1, Land Resource Division, Tolworth, England.

Okpara D. A., \& Ibiam, B. (2000). Evaluation of soyabean varieties for adaptability to a humid tropical environment in south east Nigeria. Journal of Sustainable Agriculture and Environment, 2, $26-31$.

Osborne, S., \& Riedell, W. E. (2006). Soyabean growth response to low rates of nitrogen applied at planting in the Northern Great Plains. Journal of Plant Nutrition, 29, 985-1002. http://dx.doi.org/10.1080/01904160600686007

Paz, J. O., Batchelor, W. D., Colvin, T. S., Logsdon, S. D., Kasper, T. C., \& Karlen, D. L. (1998). Calibration of a crop growth model to predict spatial yield variability. Trans. American Society of Agricultural Engineering, $41,1527-1534$.

Phillipine Council for Agriculture and Resource Research and Development (PCARRD) / United State Department of Agriculture (USDA). (1986). Environmental adaptation of crops. PCARRD Books series No. 37, Los Banos, Laguna, Phillipines.

Salvagiotti, F., Cassman, K., Specht, J., Walters, D, Weiss, A., \& Dobermann, A. (2008). Nitrogen uptake, fixation and response to fertilizer $\mathrm{N}$ in soyabeans: A review. Field Crops Research, 108, 1-13. 
http://dx.doi.org/10.1016/j.fcr.2008.03.001

Sanginga, N., Dasheill, K., Okogun, J. A., \& Thottappilly, G. (1997). Nitrogen fixation and N contribution by promiscuous nodulating soybeans in the southern Guinea savanna of Nigeria. Plant and Soil, 195, 257-266. http://dx.doi.org/10.1023/A:1004207530131

Singh, P., Boote, K. J., Rao, Y. A., Iruthayaraj, M. R., Sheikh, A. M., Hundal, S. S., \& Narang, R. S. (1994). Evaluation of the groundnut model PNUTGRO for crop response to water availability, sowing dates, and seasons. Field Crops Research, 39, 147-162. http://dx.doi.org/10.1016/0378-4290(94)90017-5

Soil Conservations Service (SCS). (1972). National Engineering Handbook, Hydrology Section 4, Chapters 4-10.

Starling, M., Weaver, D., \& Wood, W. (1998). Nitrogen improves yield of late planted soybeans. Highlights of Agricultural Research, 45, 18-19.

Steel, R. G. D., \& Torrie, J. H. (1987). Principles and Procedures of Statistics: A Biometrical Approach (2nd Ed.). McGrawHill Book Company, London, U.K.

Steve, O. A., \& Jonathan, J. A. (2001). Correlation studies on Melordogyne Incognita induced root galls and some growth parameters of four elite varieties of Glycine Max (L) Merrill. Tropical Oilseed Journal, 6, 93-97.

Tanimu, B., \& Yayock, J. Y. (1990). Bambaranut Agronomy. In Cropping Scheme Report 1990. Legumes and oilseeds research programme. Ahmadu Bello University, Institute of Agricultural Research, Zaria, Nigeria.

Taylor, J., Whelan, B., Thylén, L., Gilbertsson, M., \& Hassall, J. (2005). Monitoring wheat protein content on-harvester-Australian experiences. In J Stafford et al. (Eds.), Proceeding of 5th European Conference on Precision Agriculture, Uppsala, Sweden (9-12 June, 2005, pp. 369-376). Wageningen Academic Publisher, Wageningen.

Thierfelder, C., Amezquita, E., \& Stahr, K. (2005). Effects of intensifying organic manuring and tillage practices on penetration resistance and infiltration rate. Soil and Tillage Research, 82, 211-226. http://dx.doi.org/10.1016/j.still.2004.07.018

Tiamigu, S. A., \& Idowu, A. A. (2001). Economics of resource use among small scale soybean farmers in Niger State. Tropical Oilseeds Journal, 6, 71-75.

Tsuji, G. Y., Uehara, G., \& Balas, S. (1994). International Benchmark Sites Network for Agrotechnology Transfer, DSSAT (Version 3, Vol. 1). University of Hawaii, Honolulu, Hawaii.

United States Department of Agriculture. (2006). Keys to Soil Taxonomy (10th Ed., p. 331). Soil Survey Staff. Natural Resources Conservation Service.

United States Department of Agriculture. (2010). Keys to Soil Taxonomy (11th Ed., p. 346). Natural Resources Conservation Service.

Williams, J. R., Jones, C. A., \& Dyke, P. T. (1984). A modeling approach to determining the relationships between erosion and soil productivity. Transactions of the ASAE, 27, 129-144. http://dx.doi.org/10.13031/2013.32748

Yusuf, L. A., \& Idowu A. A. (2000). Evaluation of four soyabean varieties for performance under different lime regimes on the acid soil of Uyo. Tropical Oilseed Journal, 6, 65-70.

\section{Copyrights}

Copyright for this article is retained by the author(s), with first publication rights granted to the journal.

This is an open-access article distributed under the terms and conditions of the Creative Commons Attribution license (http://creativecommons.org/licenses/by/3.0/). 